\title{
Экспресс-информация
}

УДК 551.32

doi: $10.15356 / 2076-6734-2017-3-427-432$

\section{Vast ice depression in Dålk Glacier, East Antarctica}

\author{
S.V. Popov ${ }^{*}$, S.S. Pryakhin ${ }^{2}$, D.P. Bliakharskii ${ }^{3}$, G.V. Pryakhina ${ }^{4}$, S.V. Tyurin ${ }^{4}$
}

${ }^{1}$ Polar Marine Geosurvey Expedition, St. Petersburg, Russia; ${ }^{2}$ Arctic and Antarctic Research Institute, St. Petersburg, Russia; ${ }^{3}$ SE Geoscan, St. Petersburg, Russia; ${ }^{4}$ Saint Petersburg State University, St. Petersburg, Russia

*spopov67@yandex.ru

\section{Обширная депрессия в леднике Долк, Восточная Антарктида}

\section{(С) 2017 г. С.В. Попов ${ }^{1 *}$, С.С. Пряхин ${ }^{2}$, Д.П. Бляхарский ${ }^{3}$, Г.В. Пряхина ${ }^{4}$, С.В. Тюрин ${ }^{4}$}

${ }^{1}$ Полярная морская геологоразведочная экспедиция, Санкт-Петербург, Россия; ${ }^{2}$ Арктический и Антарктический научноисследовательский институт, Санкт-Петербург, Россия; ${ }^{3} \mathrm{AO}$ Геоскан, Санкт-Петербург, Россия; ${ }^{4}$ Санкт-Петербургский государственный университет, Санкт-Петербург, Россия

*spopov67@yandex.ru

Поступила 4 апреля 2017 г.

Принята к печати 14 мая 2017 2.

Ключевые слова: антарктическая гляциология, подледниковые паводки, гляциальная гидрология, йокульлауп, субгляциальные процессы.

30 января 2017 г. на участке дороги, соединяющей российскую станцию Прогресс и китайскую станцию Зонгшан с аэродромом и трассой следования санно-гусеничных походов на внутриконтинентальные станции Восток и Кунлун, в западной части ледника Долк (Dålk Glacier), в районе российской полевой базы Прогресс-1 образовался провал. Дана характеристика этого провала.

Received April 4, 2017

Accepted May 14, 2017

Keywords: Antarctic glaciology, glacier hydrology, jökulhlaups, subglacial processes, subglacier floods.

\section{Summary}

In the afternoon of January 30,2017, the wide depression in the western part of the Dålk Glacier, East Antarctica, was formed. By coincidence, aerial surveying was carried out in this area, so it is possible to assess the extent of this catastrophic phenomenon. Aerial photos were taken on January 20 and February 9, 2017, respectively. Based on the photographic data, the size of the depression were $183 \times 220 \mathrm{~m}$, and its area reached $40.260 \mathrm{~m}^{2}$. The depth of the depression in the early days was 20-30 meters; the maximum measured depth was $43 \mathrm{~m}$. An approximate volume of the cavern was about $884,013 \mathrm{~m}^{3}$. On preliminary conclusions, this event should be the similar jökulhlaups, when the water of Boulder Lake broke the icy border and rushed downstream under Dålk Glacier to Prudz Bay.

Citation: Popov S.V., Pryakhin S.S., Bliakharskii D.P., Pryakhina G.V., Tyurin S.V. Vast ice depression in Dålk Glacier, East Antarctica. Led i Sneg. Ice and Snow. 2017, 57 (3): 427-432. doi: 10.15356/2076-6734-2017-3-427-432

In the afternoon of January 30, 2017, in the western part of the Dålk Glacier, near the Russian field base Progress-1, a depression formed on the fragment of the road connecting the Russian station Progress and the Chinese station Zongshan with the airfield and the logistic traverse to the inland Vostok and Kunlun stations. During the austral summer field season, by coincidence, aerial surveying was carried out in this area, so it is possible to assess the extent of this catastrophic phenomenon. Sections $a$ and $b$ of
Fig. 1 show a fragment of the orthophoto of the depression area before and after the event. In section $c$ of the same figure, its enlarged image is displayed. Aerial photos were taken on January 20 and February 9, 2017, respectively. They were processed using Agisoft PhotoScan 1.2 software package (Agisoft LLC, Russia), which implements a modern technology of creating three-dimensional models based on digital photos. This makes it possible to perform a morphometric analysis of the natural feature under study. 

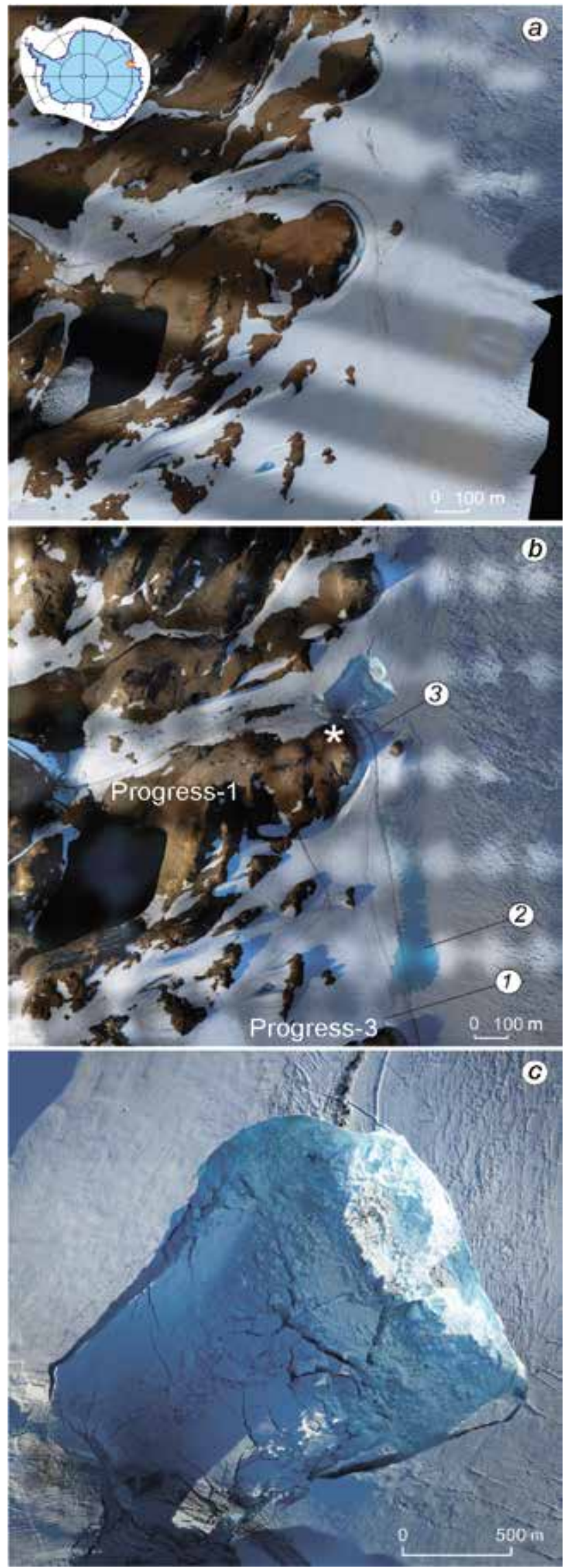

Fig. 1. Ice depression area near Russian fieldbase Progress- 1 before event $(a)$, after event $(b)$, and enlarged depression $(c)$.

1 - water channel from Boulder Lake; 2 - wet (?) blue spot; 3 - water channel near Progress-1. The white star is marking the place of the photo in Fig. 2, $a$. Ortophoto on $a$ was obtained on January 20, 2017, the other ones were obtained on February 9, 2017

Рис. 1. Депрессия в леднике рядом с российской полевой базой Прогресс-1 до (a) и после события $(b)$, а также увеличенное изображение депрессии $(c)$.

1 - канал, заполненный водой, вытекающей из озера Болдер; 2 влажное (?) голубое пятно на фотографии; 3 - канал, заполненный водой, расположенный рядом с полевой базой Прогресс-1. Белой звёздочкой показано место, с которого выполнена фотография, представленная на рис. 2, $a$. Ортофотография, представленная на $a$ выполнена 20 января 2017 г., остальные фотографии сделаны 9 февраля 2017 г. 


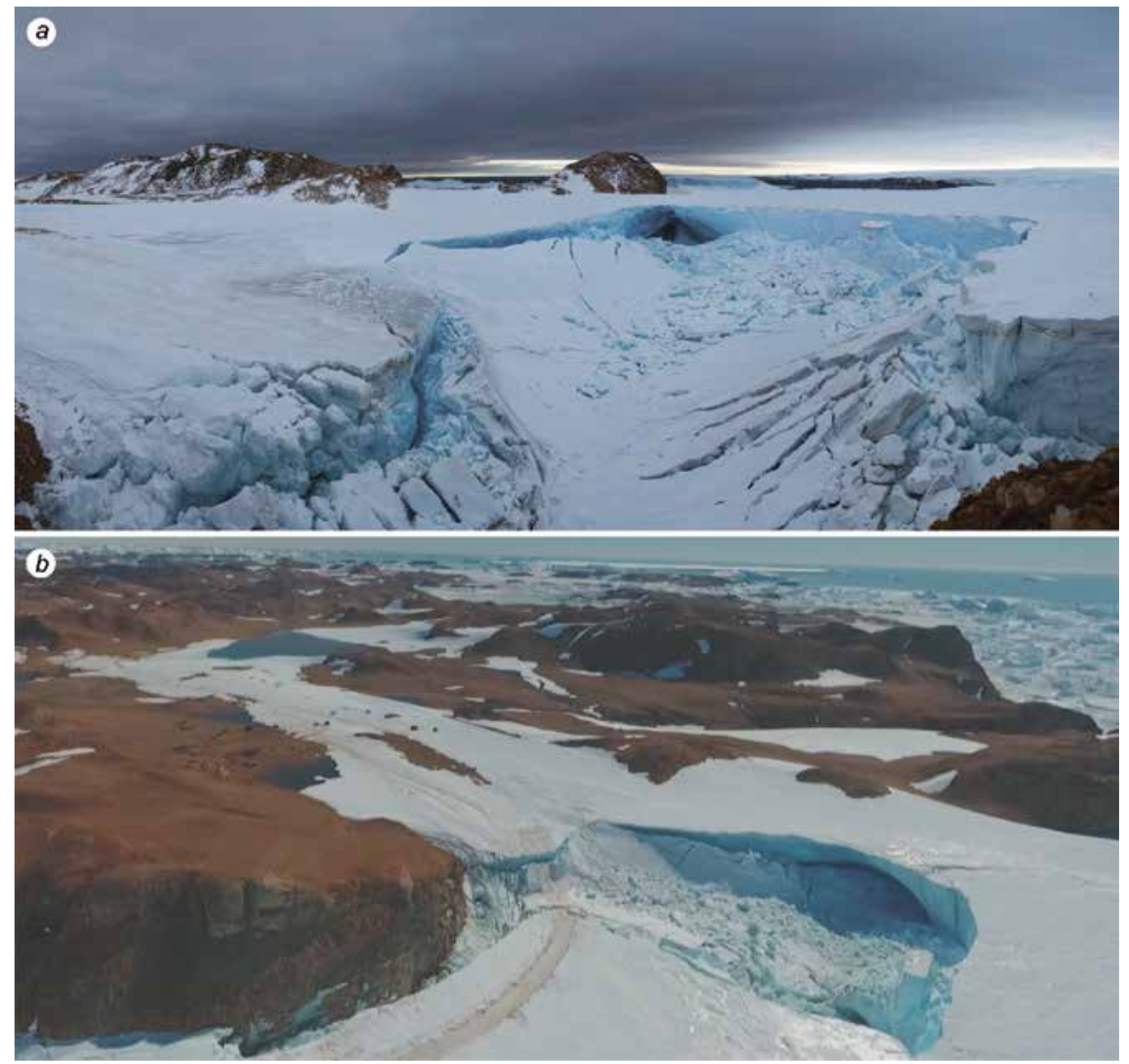

Fig. 2. Photos of the depression from the ground $(a)$ and from a dron $(b)$.

Photo on section $a$ was taken by S.S. Pryakhin. Location of the photo is shown in Fig. $1, b$. Photo on section $b$ was presented by A.V. Mirakin, the Leader of Progress Station

Рис. 2. Фотографии депрессии, выполненные с поверхности земли $(a)$ и с борта беспилотного летательного аппарата $(b)$.

Фотография, представленная на $a$, выполнена С.С. Пряхиным. Положение места съёмки показано на рис. $1, b$. Фотография на $b$ предоставлена начальником станции Прогресс А.В. Миракиным

The orthophoto and the three-dimensional model of the feature allowed estimating the maximum linear dimensions of the forming depression, which were $183 \times 220 \mathrm{~m}$, and its area reached $40,260 \mathrm{~m}^{2}$. According to the preliminary assessment, the depth of the depression in the early days was 20-30 m; the maximum measured depth was $43 \mathrm{~m}$.
An approximate volume of the cavern was about $884,013 \mathrm{~m}^{3}$. Unfortunately, the above event occurred at the end of the field season, shortly before the departure of the seasonal team from the Progress station. Thus, it was impossible to accomplish the necessary set of geophysical and glaciological studies. However, the reconnaissance observations were car- 
ried out, which made it possible to draw only preliminary conclusions.

In the photo (see Fig. 1, b) obtained in the course of aerial surveying, channel 1 flowing out from Boulder Lake is clearly seen adjoining the western part of the hill on which the Russian field base Progress-3 is located. Further northwards, downstream, within the Dålk Glacier, there is a bright blue spot 2 (see Fig. 1, $b$ ). It lies within the feature marked as a lake in the Australian maps [1]. Possibly, after the breakthrough of Boulder Lake, water along the under-ice channels flowed into it, filled it to the margin, and then burst through. Water flowed further coming to the surface as drain channel 3, directly adjacent to the eastern part of the hill, near the northern slope of which the Russian field base Progress-1 (see Fig. 1, b) is located. This process was promoted by numerous crevasses in the area [2] which disturb the integrity of the glacier. Further, water along the existing as well as the forming channels flowed under the Dålk Glacier eroding and collapsing the cavern, which, probably, had already existed there for some time. The rapidly flowing lake water was visually observed at various sites, between the field base Progress- 3 and the formed depression. Then, under the Dålk Glacier, it rushed to the Prydz Bay. A large under-ice channel is clearly seen in the photos in Fig. 2.

A similar process of subglacial floods called using the Icelandic term jökulhlaups [3] has been repeatedly discussed in the scientific papers with reference to the subglacial hydrosphere of the Antarctica [4-8]. Thus, proceeding from the preliminary information and description of similar phenomena, the process of the depression formation can be presented as follows. In the lake basin of Boulder Lake, in the process of melted glacial water inflow, water accumulated gradually (the accumulation period could be several years). Lakes of this type, as a rule, are not emptied by a simple overflow. When the water level reached a certain critical point, as a result of hydrostatic pressure and thermal expansion of the drain channels, a breakthrough in the weakest place occurred. Due to the excess of water temperature over the temperature of the melting ice and the heat released during the movement of the water flow, the breakthrough developed rapidly resulting in formation of a channel for the drainage of lake water. In the process of lake emptying, the cross-sectional area of the channel increases, and hydrostatic pressure drops as the lake water volume is reduced. Outflow from the lake occurred until the water level fell below the height of the drain threshold. Further, judging by the photo, the channel got into a grotto or a crevasse and moved further not too deep under the surface spreading in the snow firn sequence. Presumably, water gradually filled the interglacial cavity in the area of the depression formation, which, in turn, caused a breakthrough, emptying along the interglacial channels towards the ocean, and, as a consequence, ice subsidence in the form of a depression, and further drainage of water into the Prydz Bay.

The described event is of great scientific interest. In addition, it is of great practical importance in the light of the study of subglacial reservoirs and the under-ice hydrographic network as a whole. At similar unique features located near the infrastructure of the polar stations, it is possible to directly study the equivalents of the processes occurring in the interior regions of the Antarctica. The practical interest to its study is associated with ensuring the safety of the movement of people and transport vehicles within the areas of the Antarctic glacier.

Acknowledgements. The authors thank A.V. Mirakin, V.V. Lukin, V.L. Martyanov for the support of the scientific works in Antarctica.

Благодарности. Авторы статьи благодарны А.В. Миракину, В.В. Лукину и В.Л. Мартьянову за поддержку в организации научных работ в Антарктиде.

\section{Расширенная русскоязычная аннотация}

Днём 30 января 2017 г. на участке дороги, соединяющей российскую станцию Прогресс и китайскую станцию Зонгшан с аэродромом и трассой следования санно-гусеничных походов на внутриконтинентальные станции Восток и Кунлун, в западной части ледника Долк (Dålk Glacier), в районе российской полевой базы Прогресс-1 образовался провал. В летний полевой сезон в этом районе выполнялась аэрофотосъёмка, что позволяет оценить масштабы данного катастрофического явления. На рис. $1, a$ и $b$ показан фрагмент ортофотоплана района провала до и после события. В секции $c$ того же рисунка приводится укрупнённое его изображе- 
ние. Аэрофотосъёмка выполнена 20 января и 9 февраля 2017 г. соответственно. Ортофотоплан и трёхмерная модель объекта позволили оценить максимальные линейные размеры образовавшейся депрессии - $183 \times 220$ м, а её площадь составила $40260 \mathrm{~m}^{2}$. Согласно предварительной оценке, глубина провала в первые дни была равна 20-30 м, а максимальная измеренная глубина составила 43 м. Приблизительный объём каверны - около $884013 \mathrm{~m}^{3}$.

На фотографии (см. рис. $1, b$ ), полученной в процессе аэрофотосъёмки, отчётливо наблюдается канал 1, вытекающий из озера Болдер (Boulder Lake) и примыкающий к западной части холма, где расположена российская полевая база Прогресс-3. Далее, на север, вниз по течению, в пределах ледника Долк, наблюдается голубое пятно 2 (см. рис. $1, b)$. Оно располагается в пределах объекта, помеченного на австралийских картах [1] как озеро. Вероятно, после прорыва оз. Болдер вода по подлёдным каналам поступила в озеро, наполнила его до краёв, а затем произошёл прорыв. Вода потекла далее, выйдя на поверхность в виде канала стока 3, непосредственно примыкающего к восточной части холма, у северного склона которого находится российская полевая база Прогресс-1 (см. рис. $1, b)$. Этому процессу способствовали многочисленные трещины, имеющиеся в этом районе [2] и нарушающие целостность ледника. Вода по существующим, а также образовавшимся каналам поступила под ледник Долк, размыв и обвалив каверну, которая там, вероятно, уже существовала какое-то время (см. рис. $1, b$ ). Стремительно текущая озёрная вода визуально наблюдалась на различных участках между полевой базой Прогресс-3 и образовавшейся депрессией. Затем она устремилась в залив Прюдс. Значительный по размерам подлёдный канал отчётливо виден на фотографиях рис. 2.

Подобный процесс подледниковых паводков, названный исландским термином йокульлауn [3], неоднократно обсуждался в научной печати применительно к подлёдной гидросфере Антарктиды [4-8]. Таким образом, основываясь на предварительной информации и описании сходных явлений, процесс образования провала можно представить следующим образом. В озёрной чаше оз. Болдер в процессе поступления талых ледниковых вод постепенно накапли- валась вода (период накопления может достигать нескольких лет). Озёра подобного типа, как правило, не опорожняются путём простого перелива. При достижении водой некоторой критической отметки, в результате гидростатического давления и термического расширения каналов стока в самом слабом месте формируется прорыв. За счёт превышения температуры воды над температурой тающего льда и тепла, выделяемого при движении водного потока, прорыв быстро развивается и в результате формируется канал стока озёрной воды. В процессе опорожнения озера увеличивается площадь поперечного сечения канала и уменьшается гидростатическое давление по мере снижения объёма озёрной воды. Истечение из озера происходит до тех пор, пока уровень воды не упадёт ниже высоты сливного порога. Затем, судя по снимку, канал уходит в грот или трещину и дальше двигается не слишком глубоко под поверхностью, растекаясь в снежно-фирновой толще. Предположительно водный поток постепенно заполнил внутриледниковую ёмкость, находившуюся в районе образования провала, что, в свою очередь, вызвало прорыв, опорожнение по внутриледниковым каналам в сторону океана и, как следствие, просадку льда в виде провала и дальнейший слив воды в залив Прюдс.

Описанное событие имеет большой научный интерес. Не менее важно и прикладное его значение для изучения подледниковых водоёмов и подлёдной гидросети в целом. На подобных уникальных объектах, расположенных вблизи инфраструктуры полярных станций, можно непосредственно изучать аналоги процессов, происходящих во внутренних районах Антарктиды. Прикладной интерес к его исследованию связан с обеспечением безопасности перемещения людей и транспортной техники в пределах участков антарктического ледника.

\section{References}

1. Broknes Peninsula, Larsemann Hills, Antarctica: environmental management map. Map No 13135, 2005, Scale 1:10,000, Australian Antarctic Division.

2. Popov S.V., Eberlein L. Investigation of snow-firn thickness and ground in the East Antarctica by means of geophysical radar // Ice and Snow. 2014. V. 4 (128). 
P. 95-106. doi: 10.15356/2076-6734-2014-4-95-106. [In Russian with English summary]

3. Björnsson H. Subglacial lakes and jökulhlaups in Iceland // Glob. Planet. Change. 2003. V. 35. № 3-4. P. 255-271. doi: 10.1016/S0921-8181(02)00130-3.

4. Evatt G.W., Fowler A.C., Clark C.D., Hulton N.R.J. Subglacial floods beneath ice sheets // Philosophical Transaction. A. Mathematics. Physics. Engeneering Sciences. 2006. V. 364. № 1844. P. 1769-1794. doi: 10.1098/rsta.2006.1798.

5. Fowler A.C. Dynamics of subglacial floods // Proc. Royal Society. A. Mathematical Physics. Engineering
Sciences. 2009. V. 465. № 2106. P. 1809-1828. doi: 10.1098/rspa.2008.0488.

6. Pattyn F. Antarctic subglacial lake discharges // Antarctic Subglacial Aquatic Environments. 2013. AGU. P. 27-44. doi: 10.1002/9781118670354.ch3.

7. Shoemaker E.M. Effects of bed depressions upon floods from subglacial lakes // Global Planet Change. 2003. V. 35. № 3-4. P. 175-184. doi: 10.1016/S0921-8181(02)00125-X. 8. Wingham D.J., Siegert M.J., Shepherd A., Muir A.S. Rapid discharge connects Antarctic subglacial lakes // Nature. 2006. V. 440. № 7087. P. 1033-1036. doi: 10.1038 /nature 04660 .

Подписано в печать 04.09.2017 г. Выход в свет 30.09.2017 г. Формат $60 \times 881 / 8$

Цифровая печать $\quad$ Усл.печ.л. $18.0 \quad$ Усл.кр.-отт. 7.2 тыс. $\quad$ Уч.-изд.л. 18.0 Бум.л. 9.0 Тираж 170 экз. Зак. 1446 Цена свободная

Соучредители: Российская академия наук, Русское географическое общество

Издатель: ФГУП «Издательство «Наука», 117997, Москва, Профсоюзная ул., 90

Отпечатано в ФГУП «Издательство «Наука» (Типография «Наука»), 121099, Москва, Шубинский пер., 6 